\title{
MODELING THE GROWTH OF EUCALYPTUS PLANTS BASED ON THE THERMAL SUM'
}

\author{
Aline Santana de Oliveira ${ }^{2}$, Aristides Ribeiro ${ }^{3 *}$, Carla Raphaela Araújo Silva ${ }^{4}$, Aloísio Xavier ${ }^{5}$ and Alex
} Ferreira de Freitas ${ }^{6}$

\footnotetext{
${ }^{1}$ Received on 08.10.2013 accepted for publication on 27.10.2016.

${ }^{2}$ Universidade Federal de Viçosa, Programa de Pós Graduação em Meteorologia Agrícola, Viçosa, MG - Brasil. E-mail: $<$ aline.s.oliveira@ufv.br>.

${ }^{3}$ Universidade Federal de Viçosa, Departamento de Engenharia Agrícola, Viçosa, MG - Brasil. E-mail: <ribeiro@ufv.br>.

${ }^{4}$ Universidade Federal de Viçosa, Graduanda em Engenharia Florestal, Viçosa, MG - Brasil. E-mail: <carlaraphaelaufv@gmail.com>.

${ }^{5}$ Universidade Federal de Viçosa, Departamento de Engenharia Florestal, Viçosa, MG - Brasil. E-mail: <xavier@ufv.br>.

${ }^{6}$ Universidade Federal de Viçosa, Programa de Pós Graduação em Engenharia Florestal, Viçosa, MG - Brasil. E-mail: $<$ alexffreitas@yahoo.com.br>.

*Corresponding author.
}

\begin{abstract}
Among the environmental variables that affect the growth and development of plants, the air temperature is of great importance. In this context, the objectives of this work were to model the growth of eucalyptus seedlings in terms of accumulated degree-days during the production process and model validation. The study was conducted in the forest research nursery of the Department of Forestry, located in Viçosa (MG), during the periods of 08/02/2011 to 28/04/2011 and 03/08/2012 to 01/11/2012, making it possible to contemplate seasonal variations in the production cycle. The monitored variables were shoot height, stem diameter, leaf area, root length and fresh and dry biomass. Results showed that it took 1065 degree-days for the production of seedlings and sigmoidal models obtained showed high correlation and Willmott coefficients, indicating good performance for estimating the growth and development of eucalyptus seedlings. This tool has great potential for planning and monitoring the production of eucalyptus seedlings in nurseries.
\end{abstract}

Keywords: Degree-days; Forestry; Sigmoidal model

\section{MODELAGEM DO CRESCIMENTO DE MUDAS DE EUCALIPTO COM BASE NA SOMA TÉRMICA}

\begin{abstract}
RESUMO - Dentre as variáveis ambientais que afetam o crescimento e desenvolvimento das plantas, a temperatura do ar é de grande importância. Nesse contexto, os objetivos desse trabalho foram realizar a modelagem do crescimento de mudas de eucalipto em função dos graus-dia acumulados no decorrer do processo de produção e a validação do modelo proposto. O estudo foi realizado no viveiro de pesquisas florestais pertencente ao Departamento de Engenharia Florestal, localizado em Viçosa (MG), nos períodos de 08/02/2011 a 28/ 04/2011 e 03/08/2012 a 01/11/2012, sendo possivel contemplar as variações sazonais no ciclo de produção. As variáveis monitoradas foram altura da parte aérea, diâmetro do colo, área foliar, comprimento do sistema radicular e biomassa fresca e seca. Resultados mostraram que foram necessários 1065 graus-dia acumulados para a produção das mudas e que os modelos sigmoidais obtidos apresentaram altos coeficientes de correlação e de Willmott, apresentando bom desempenho para estimar o crescimento e desenvolvimento das mudas de eucalipto. Esta ferramenta apresenta alto potencial para o planejamento e condução da produção de mudas de eucalipto em viveiros.
\end{abstract}

Palavras-chave: Graus-dia acumulados; Silvicultura; Modelo sigmoidal 


\section{INTRODUCTION}

Eucalyptus is a forest species of great economic, social and environmental importance for Brazil, currently occupying an area of 5.10 million hectares which grew by $4.5 \%$ in relation to the previous year. The main factor that led to this growth was the establishment of new plantations based on future demand for industrial projects in the paper and pulp segment (ABRAF, 2013).

The production of eucalyptus seedlings is mainly performed by vegetative propagation, and the minicutting technique is that most used for the production of seedlings on a commercial scale (Mafia et al., 2005). According to Xavier et al. (2013), the use of mini-cuttings allows for optimization of rooting and quality of clonal seedlings, especially clones with greater difficulty of vegetative propagation. The seedling production process of this species includes rooting, shaded acclimatization and open acclimatization phases for growth and hardening.

In addition to the technological advances achieved in recent decades regarding eucalyptus vegetative propagation techniques, it is also important to analyze the influence of climatic variables on the growth and development of plants. Among these variables, the air temperature is of great importance since it interferes with the vapor pressure deficit and consequently the mechanism of opening and closing the stomata, the absorption of $\mathrm{CO}_{2}$, the distribution of photoassimilates and biomass production (Taiz and Zeiger, 2013).

According to Streck (2004), the first quantitative study of the plant-temperature relationship is attributed to René Réaumur, in about 1730 (Réaumur, 1735). From this, a simple and widely used method to evaluate the effect of temperature on the growth and development of plants could be expressed based on the concept of cumulative degrees-days or thermal sum. The thermal sum represents the accumulation of a given amount of energy in a lower and higher basal temperature range that a crop needs to reach a certain stage of development.

Although simple, the thermal sum concept has been the objective of many recent studies (Neis et al., 2010; Wagner et al., 2011; Camparotto et al., 2012; Moura et al., 2012; Palaretti et al., 2012; Batista et al., 2013), where for the process of producing eucalyptus seedlings its utilization provides different advantages. These include planning the use of structures applied during the seedlings production process, estimating the duration and number of cycles at different times of the year and for different genetic materials, as well as to predict the availability date of seedlings for implantation.

A recent study (Oliveira et al., 2012) showed that the concept of accumulation of degree-days is useful to determine the duration of the rooting phase and growth modeling in this initial phase of seedling development. This allows for inferring on the potential of studies of this type for decision making in the management in eucalyptus seedling nurseries.

Given the above, the objective of the present work was to model the growth of eucalyptus seedlings based on the thermal sum followed by validation of the proposed model.

\section{MATERIALAND METHODS}

The experiment was carried out at the Research Nursery of the Forestry Engineering Department in Viçosa, Minas Gerais, Brazil, from February 8, 2011 to April 28, 2011 and from August 3, 2012 to November 1,2012 . The region presents average annual rainfall of $1,220 \mathrm{~mm}$, average maximum temperature of $26^{\circ} \mathrm{C}$ and average minimum of $14^{\circ} \mathrm{C}$.

The production of eucalyptus seedlings was performed in a greenhouse adapted to meet all phases in the environment, with dimensions of $6 \times 6 \times 3 \mathrm{~m}$ (width, length and height). The structure was covered with a low density polyethylene (LDPE) plastic film, with a thickness of $150 \mathrm{ìm}$, and moveable shade with $60 \%$ mesh. The sides of the structure had metal hinges that allowed for their opening when the production phase changed.

Cuttings of a commercial clone (Eucalyptus grandis $\mathrm{x}$ E. urophylla) supplied by the Empresa Celulose NipoBrasileira S.A. (CENIBRA) were used, which measured approximately $10 \mathrm{~cm}$ in height and had two pairs of leaves, and the leaf area was reduced by $40 \%$ in order to decrease transpiration.

The recipients used in production of the seedlings were polypropylene tubes, with a volume capacity of $55 \mathrm{~cm}^{3}$ and a height of $12.5 \mathrm{~cm}$, filled with a commercial substrate mixture (MecPlant $\AA$ ) enriched with single superphosphate $\left(6 \mathrm{~kg} \mathrm{~m}^{-3}\right)$ and Osmocote $\mathbb{R}$ (19-6-10) $\left(3 \mathrm{~kg} \mathrm{~m}^{-3}\right)$. After the rooting phase, broadcast fertilization was carried out with monoammonium phosphate (MAP) 
in the proportion of $150 \mathrm{~g}$ of the fertilizer to $10 \mathrm{~L}$ of water, and $5 \mathrm{~mL}$ of this solution was applied to each tube.

Planting of the cuttings was conducted in plastic trays with capacity for 96 tubes. In the acclimatization, growth and hardening phases, only 48 cells of each tray were occupied in order to avoid the formation of a microenvironment favorable to the occurrence of diseases.

The seedling production structure was equipped with a temperature and relative humidity sensor connected to a digital controller (N323 RHT, Novus, Brazil) installed in the central part of the structure used for production of the eucalyptus seedlings, at the height of the plant canopy. The values of air temperature and humidity were stored in a computer, where the means of the variables were obtained at a frequency of one minute.

In the rooting phase irrigation of the seedlings was carried out by a misting system, formed of 100 mist nozzles with individual flow of $7.5 \mathrm{~L} \mathrm{~h}^{-1}$, which was activated for 20 seconds when the temperature inside the green house was above $30^{\circ} \mathrm{C}$ or the relative humidity was below $85 \%$. In acclimatization, irrigation was performed by means of nine micro-sprinklers with individual flow rates of $120 \mathrm{~L} \mathrm{~h}^{-1}$ and 64 mist nozzles with unit flow rate of $7.5 \mathrm{~L} \mathrm{~h}^{-1}$, activated four times a day $(8,12,14$ and $16 \mathrm{~h})$ and the system remained on for five minutes. In addition, the shading screen remained extended to reduce exposure of the seedlings to solar radiation. During the growth period, the irrigation system consisted of the same nine micro-sprinklers and 64 mist nozzles, but it was only activated twice a day (10 and $15 \mathrm{~h}$ ) for 10 minutes. In hardening, the application of water occurred twice per day, but for eight minutes. In the growth and hardening phases the sides of the protected environment remained open and the shading screen removed.

The end of the rooting phase was characterized by the presence of roots in the lower orifice of the tubes, cutting the roots that exited the tube so their size was limited to $12 \mathrm{~cm}$.

In the acclimatization phase the shading screen was maintained for ten days to complete the rhizogenesis process of the cuttings. The end of the growth stage was characterized by the change in color of the leaves and a slight hardening of the stem. At the end of hardening greater stiffness of the stem was observed, where it did not remain curved after passing one's hand in the horizontal direction and the leaves presented reddish coloration (Ribeiro et al., 2001).

The methodology proposed by Villa Nova (1972) was used to calculate the cumulative degree-days, considering cases I to IV. According to Martins et al. (2007), the lower basal temperature for development of Eucalyptus grandis seedlings was considered to be $10{ }^{\circ} \mathrm{C}$. The upper basal temperature considered was $36{ }^{\circ} \mathrm{C}$ (Almeida et al., 2004).

To determine the increase in biomass of eucalyptus seedlings the destructive method was adopted, in which from the date of planting the cuttings, the fresh biomass of each of the cuttings present in on tray was measured every 3 days. The cuttings were then oven dried at $65^{\circ} \mathrm{C}$ until a constant mass was reached to obtain the dry biomass. The fresh and dry biomass measurements were performed on a $0.01 \mathrm{~g}$ precision scale (model SA 210, Scientech, USA).

Simultaneously to the determinations of fresh and dry biomass, also made were measurements of biometric variables of leaf area (model LI 3100C, Licor Biosciences, USA), shoot height, root system length (millimeter rule) and stem diameter (caliper with precision of $0.1 \mathrm{~mm}$ ).

Biometric and fresh and dry biomass measurements were used to parameterize a mathematical model to estimate the development of the seedlings during the production cycle, where the independent variable was the accumulation of degree-days. For this the sigmoidal model was used, widely utilized in plant growth models (Silva et al., 2009; Cunha and Volpe, 2011; Lin et al., 2014) because of the good fit obtained.

In statistical analyses the Pearson correlation coefficient (r), Willmott coefficient (d), square root mean error (RMSE) and mean bias error (MBE) were used.

The period from February 8, 2011 to April 28, 2011, denominated the $1^{\text {st }}$ cycle, was used for parameterization and calibration of the model and the period from August 3, 2012 to November 1, 2012, denominated the $2^{\text {nd }}$ cycle, was used for validation of the proposed model.

\section{RESULTS}

During the first production cycle the average daily temperature inside the greenhouse varied between 18.6 and $26.8{ }^{\circ} \mathrm{C}$, the minimum between 14.2 and $21.6{ }^{\circ} \mathrm{C}$ 
and the maximum between 21.5 and $38.4^{\circ} \mathrm{C}$. In the second cycle the average daily temperature varied from 14.1 to $24.6^{\circ} \mathrm{C}$, the minimum temperature from 8.0 to $20.0^{\circ} \mathrm{C}$ and the maximum from 20.2 to $35.3^{\circ} \mathrm{C}$ (Figure 1).

Figure 2 shows the variation of biometric measurements and biomasses monitored as a function of the accumulation of degree-days, from the rooting phase to that of hardening, as well as the mathematic models adjusted for each variable.

In the $1^{\text {st }}$ cycle the height of the seedlings throughout the production process varied between $9.5 \pm 1.1 \mathrm{~cm}$ and $39 \pm 4.3 \mathrm{~cm}$, from the rooting phase to that of hardening, respectively, showing that the pronounced increase of the shoot occurred after 460 accumulated degree-days, the thermal sum at which the end of the acclimatization phase occurred. After the accumulation of approximately 950 degree-days, the height of the shoot presented a behavior with reduced growth acceleration, until the end of the production process.

The stem diameter of the seedlings varied between $1.12 \pm 0.24 \mathrm{~mm}$ and $3.21 \pm 0.43 \mathrm{~mm}$, similar to that which occurred with the height of the shoot, where after 460 accumulated degree-days it was possible to perceive a more pronounced increase in this variable.

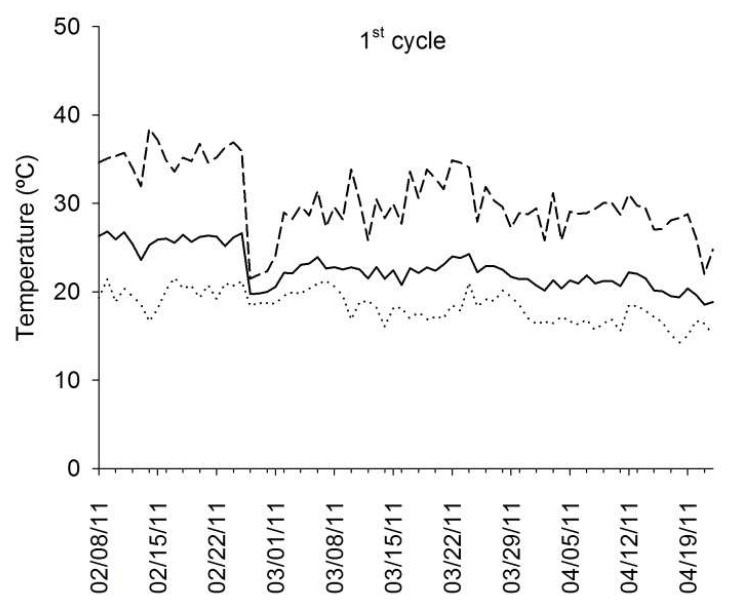

The leaf area also presented similar behavior to the height and stem diameter, in which the increase could be visualized after 460 accumulated degree-days, presenting lower development after 950 accumulated degrees-days, as explained previously. The leaf area ranged from $8.14 \pm 2.61$ to $195.41 \pm 19.04 \mathrm{~cm}^{2}$, from the beginning to the end of the production cycle.

Regarding the variation in root length as a function of cumulative day-degrees, it was verified that complete rooting of eucalyptus seedlings occurred after 317 accumulated degree-days.

At the beginning of rooting, the average fresh biomass of the cuttings was $0.28 \pm 0.09 \mathrm{~g} \mathrm{seedling}^{-1}$. At the end of hardening, the average fresh biomass of the seedlings was equal to $10.41 \pm 2.26 \mathrm{~g} \mathrm{seedling}^{-1}$. The dry biomass ranged from $0.07 \pm 0.02 \mathrm{~g}$ seedling $^{-1}$ to $1.70 \pm 0.52 \mathrm{~g} \mathrm{seedling}^{-1}$, from the beginning to the end of the first experiment.

Table 1 presents the equations obtained from variation of the biometric and biomass measurements as a function of the accumulation of degree-days and also the adjusted coefficients of determination $\left(\mathrm{r}^{2}{ }_{\text {adjus }}\right)$ for each equation. It can be observed that all sigmoidal models presented high coefficients of determination, differing with regards to the number of parameters in the equation for the different variables measured.

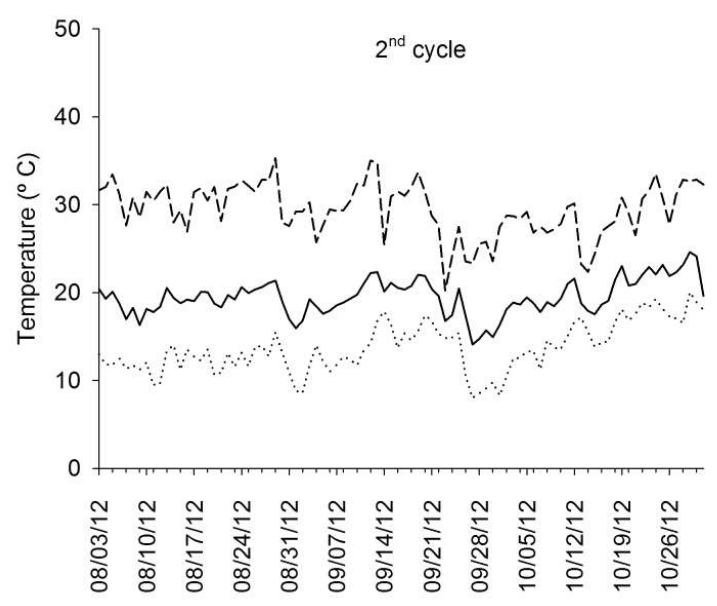

$$
\begin{aligned}
& \text { - Average temperature }\left({ }^{\circ} \mathrm{C}\right) \\
& \ldots \ldots . . \text { Minimum temperature }\left({ }^{\circ} \mathrm{C}\right) \\
& \text {---. } \text { Maximum temperature }\left({ }^{\circ} \mathrm{C}\right)
\end{aligned}
$$

Figure 1 - Variation of average, minimum and maximum temperatures $\left({ }^{\circ} \mathrm{C}\right)$ in the $1^{\text {st }}$ and $2^{\text {nd }}$ production cycles of eucalyptus seedlings.

Figura 1 - Variação das temperaturas médias, mínimas e máximas $\left({ }^{\circ} \mathrm{C}\right)$ no $1^{\circ}$ e $2^{\circ}$ ciclo de produção das mudas de eucalipto. 

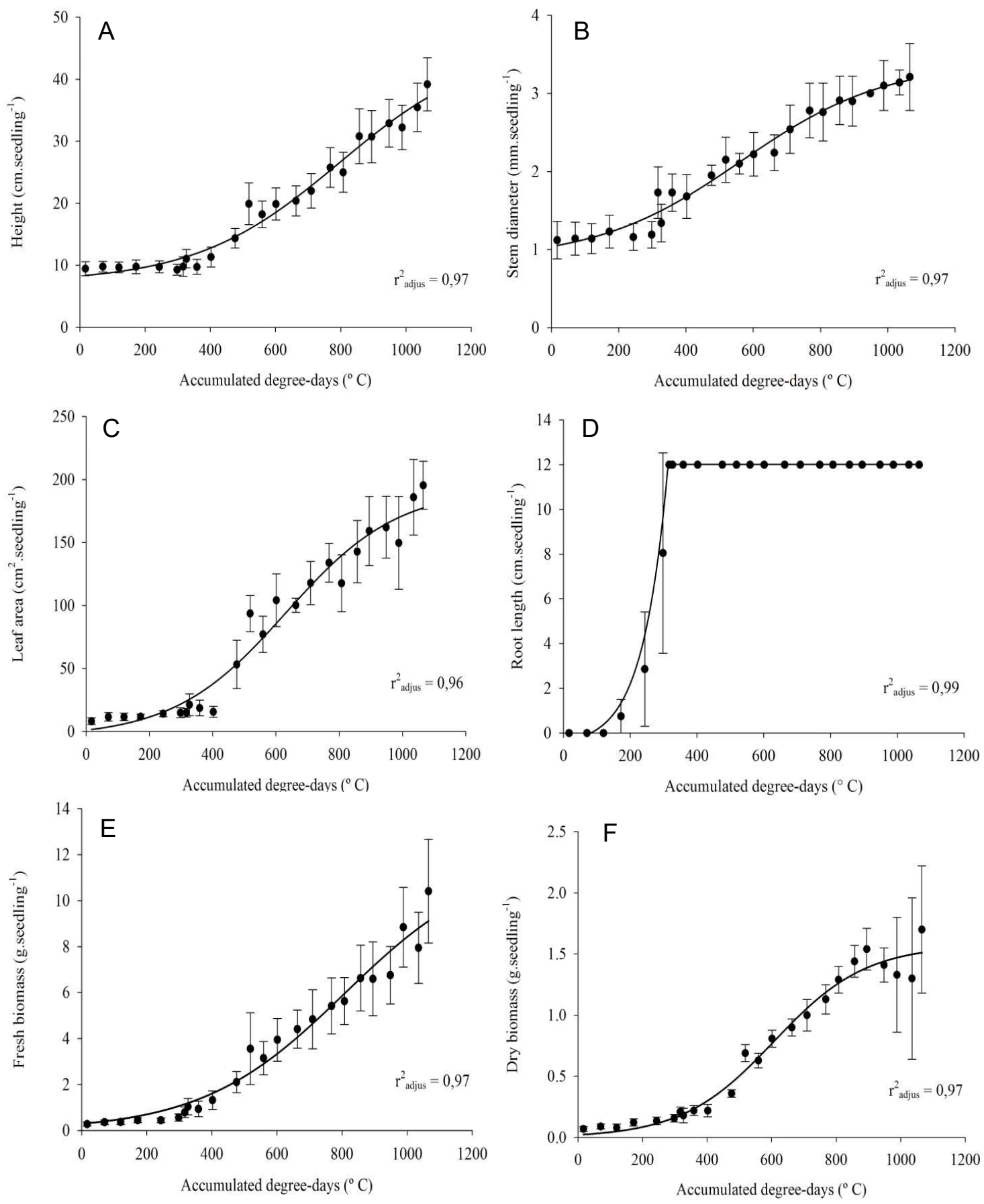

Figure 2 - Variation of the biometric measurements height (A), stem diameter (B), leaf area (C), root length (D) and fresh (E) and dry biomass (F) in function of the accumulation of degree-days and obtaining mathematical models, in Eucalyptus clones.

Figura 2 - Variação das medidas biométricas altura (A), diâmetro do colo (B), área foliar (C), comprimento radicular (D) e biomassas fresca (E) e seca (F) em função do acúmulo dos graus-dia e obtenção dos modelos matemáticos, em clone de eucalipto. 
Table 1 - Equations to estimate the variation of biometric measurements and biomass and adjusted coefficients of determination Tabela 1 - Equações de estimativa da variação das medidas biométricas e biomassas e coeficientes de determinação ajustados

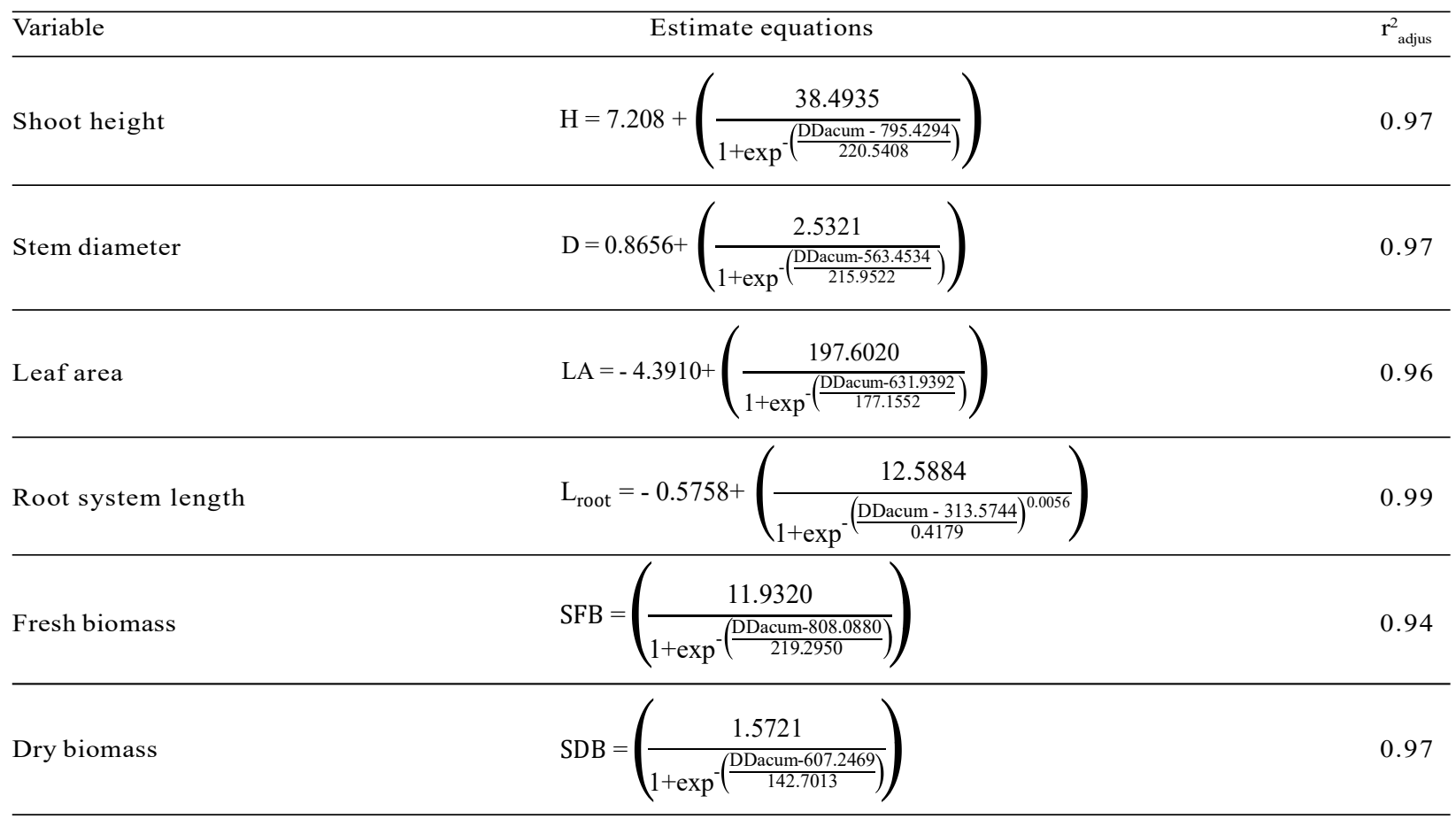

Where,

$\mathrm{H}=$ Height of the shoot, in $\mathrm{cm} \mathrm{seedling}^{-1}$;

$\mathrm{D}=$ Diameter of the stem, in mm seedling ${ }^{-1}$;

$\mathrm{LA}=$ Leaf area, in $\mathrm{cm}^{2}$ seedling ${ }^{-1}$;

$\mathrm{L}_{\text {root }}=$ root length, in cm seedling ${ }^{-1}$;

$\mathrm{SFB}=$ seedling fresh biomass, $\mathrm{g}$ seedling ${ }^{-1}$;

$\mathrm{SDB}=$ seedling dry biomass, $\mathrm{g}$ seedling ${ }^{-1}$;

$\mathrm{DD}_{\text {acum }}=$ Accumulated degree-days, ${ }^{\circ} \mathrm{Cd}$.

Figure 3 shows the results of comparisons made between the biometric and biomass measurements observed in the $2^{\text {nd }}$ cycle and the values estimated from the $1^{\text {st }}$ production cycle when using the obtained models.

Table 2 shows the thermal sum obtained at the end of each production phase, in both cycles performed.

\section{DISCUSSION}

At the end of the first production cycle the height of the seedling shoots was equal to $39 \mathrm{~cm}$ and the stem diameter equal to $3.21 \mathrm{~mm}$. Alfenas et al. (2004) stated that good quality seedlings should measure between 20 and $35 \mathrm{~cm}$ tall, have a stem diameter equal to or greater than $4 \mathrm{~mm}$, be free of diseases and symptoms of nutritional imbalance, among others. Xavier et al. (2013) affirmed that for commercial planting purposes the seedlings should present height ranging from 20 to $40 \mathrm{~cm}$ and stem diameter greater than $2 \mathrm{~mm}$. Fonseca et al. (2002) reported that the morphological characteristics and the relationships used to evaluate the quality of the seedlings should not be analyzed separately to classify the quality standard of the seedlings, so as not to risk selecting taller but weak seedlings, discarding smaller ones with greater vigor.

It was verified that the shoot height, stem diameter and leaf area presented a sigmoidal growth model with four parameters, representing a temporal progression in which at the beginning of the experiment the analyzed variable presented low development, a transition region characterized by a strong acceleration. In this case it was found after 460 accumulated degree-days, reaching a maximum after a certain time, which stabilized after 950 accumulated degree-days. 

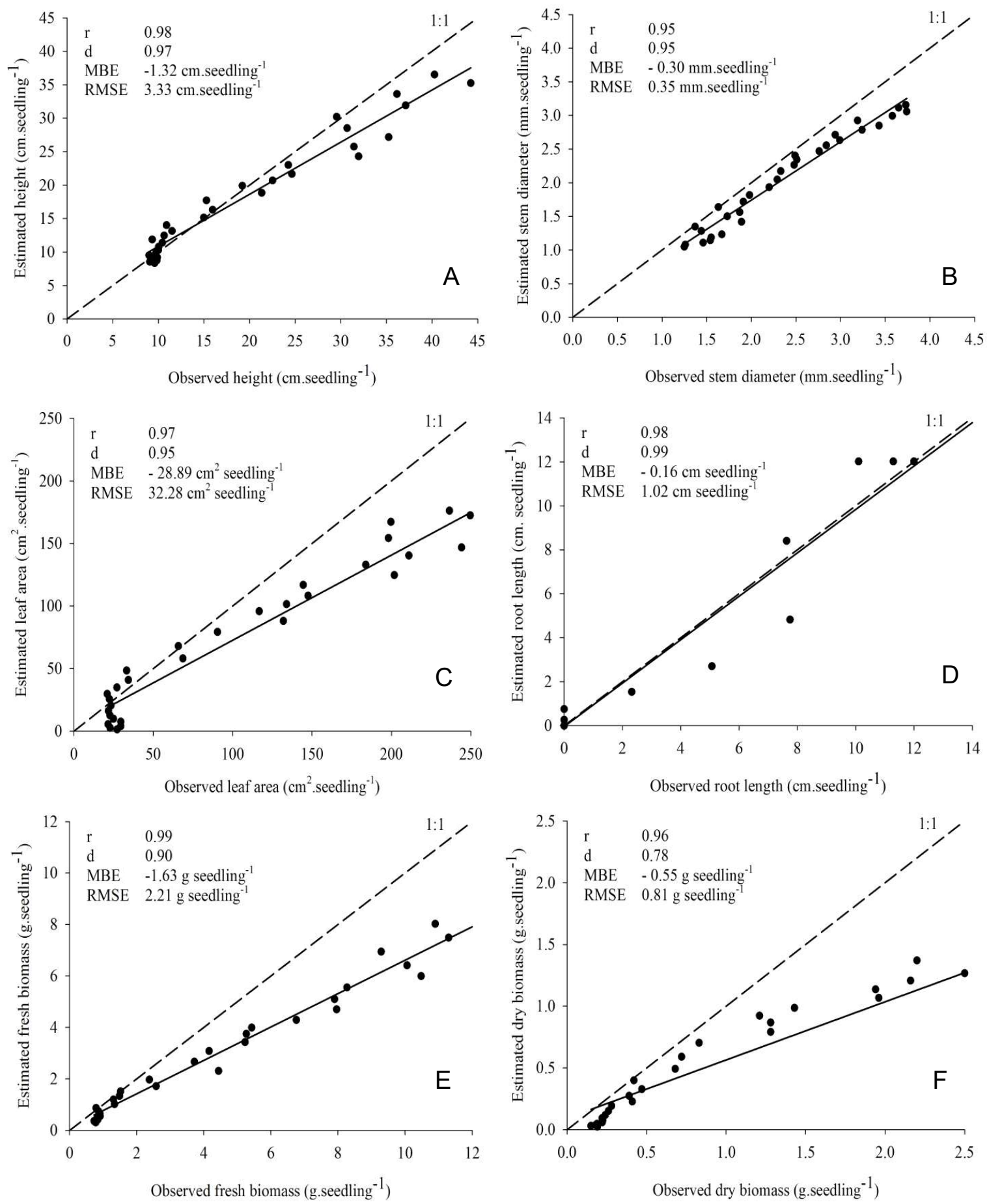

Figure 3 - Relationship between the biometric measurements height (A), stem diameter (B), leaf area (C), root length (D) and fresh (E) and dry biomass (F) observed and predicted by the models.

Figura 3 - Relação entre as medidas biométricas altura (A), diâmetro do colo (B), área foliar (C), comprimento radicular (D) e de biomassas fresca $(E)$ e seca $(F)$ estimadas e observadas pelos modelos. 
Table 2 - Thermal sum at each stage of production, in both cycles.

Tabela 2 - Soma térmica em cada fase de produção, em ambos os ciclos.

\begin{tabular}{lcc}
\hline Production phase & \multicolumn{2}{c}{ Thermal sum $\left({ }^{\circ} \mathrm{Cd}\right)$} \\
\cline { 2 - 3 } & 1st cycle & 2nd cycle \\
\hline Rooting & 317 & 327 \\
Acclimatization & 462 & 453 \\
Growth & 948 & 966 \\
Hardening & 1065 & 1049 \\
\hline
\end{tabular}

The accentuated increase in variables monitored after 460 accumulated degree-days may be related to the application of monoammonium phosphate at the beginning of the acclimation phase, where its effect was evidenced at the beginning of the growth phase. The applied fertilizer acts in photosynthesis, starch synthesis, ionic absorption, respiration and multiplication, and cell differentiation (Malavolta et al., 1997). The reduction of the growth rate at the end of the cycle can be explained by the increased respiratory activity and by self-shading, which increases with the age of the plant (Urchei et al., 2000), in addition to the limitation of root development due to the volume of substrate available, since small recipients limit the supply of nutrients (Bardiviesso et al., 2011).

The root length became constant at $12 \mathrm{~cm}$, i.e., as of 317 degree-days when the roots were observed at the lower end of the tubes, and protruding roots were cut. Oliveira et al. (2012) also stated that it took 316.42 degree-days for complete rooting of eucalyptus seedlings.

The fresh and dry biomass of the seedlings presented a sigmoidal growth model with three parameters. Silva et al. (2009) also found the same fit for total dry biomass in sunflower plants. According to Kamkar et al. (2012), the response rate of plant development to temperature can be described as a nonlinear function.

The models obtained from the monitored variables and the accumulation of degree-days in the $1^{\text {st }}$ cycle and validated by the $2^{\text {nd }}$ production cycle presented a high Pearson correlation coefficient (r), significant at 5\%, and Willmott's coefficient (d), indicating that it is an important tool to predict the growth and biomass accumulation of eucalyptus seedlings. However, according to the mean bias error (MBE), it could be inferred that the model underestimated seedling growth.
The values of height, stem diameter and root length were closer to the $1: 1$ line, indicating that the values observed in the $2^{\text {nd }}$ cycle for these variables were closer to the values estimated by the models obtained from the $1^{\text {st }}$ cycle.

The thermal sums needed to finish both production cycles were similar, however when considering the number of days, to finalize the $1^{\text {st }}$ cycle it took 80 days and for the $2^{\text {nd }}$ cycle 91 days. When analyzing the temperature variation by means of Figure 1, it was possible to verify higher temperatures in the $1^{\text {st }}$ cycle, confirming the fact that the temperature increase accelerates plant development (Taiz and Zeiger, 2013).

\section{CONCLUSIONS}

For the production of eucalyptus seedlings (Eucalyptus grandis $x$ E. urophylla) a thermal sum of 1065 degree-days was necessary, which is an estimate of the production cycle with the consequent optimized use of the facilities and prediction of the availability of seedlings for the expedition.

The sigmoid models obtained from the monitored variables and accumulated degree-days can be used to estimate the growth of eucalyptus seedlings.

It is suggested that new studies using the same methodology be carried out in other locations to validate the models under climatic conditions different from those presented in the present work.

\section{REFERENCES}

Alfenas AC, Zauza EAV, Mafia RG, Assis TF. Clonagem e doenças do eucalipto. Viçosa, MG: Universidade Federal de Viçosa; 2004. 442p.

Almeida AC, Landsberg JJ, Sands PJ. Parameterization of 3-PG model for fast-growing Eucalyptus grandis plantations. Forest Ecology and Management. 2004;193(2):179-95.

Associação Brasileira de Produtores de Florestas Plantadas - ABRAF. Anuário Estatístico da Associação Brasileira de Produtores de Florestas Plantadas 2012, Ano Base 2011. [acesso em: 9 jul. 2013] Disponível em:http://www.abraflor.org.br/ estatisticas/ABRAF12/ABRAF12-BR.pdf.

Bardiviesso DM, Maruyama WI, Reis LL, Modesto JH, Rezende WE. Diferentes substratos 
e recipientes na produção de mudas de guabiroba (Campomanesia pubescens O. Berg). Revista Científica Eletrônica de Agronomia. 2011;18(1):52-9.

Batista ELS, Zolnier S, Ribeiro A, Lyra GB, Silva TGF, Boenringer D. Modelagem do crescimento de cultivares de cana-de-açúcar no período de formação da cultura. Revista Brasileira de Engenharia Agrícola e Ambiental. 2013;17(10):1080-7.

Camparotto LB, Camargo MBP, Moraes JFL. Época provável de maturação para diferentes cultivares de café arábica para o Estado de São Paulo. Ciência Rural. 2012;42(4):594-9.

Cunha AR, Volpe CA. Curvas de crescimento do fruto de cafeeiro cv. Obatã IAC 1669-20 em diferentes alinhamentos de plantio. Semina: Ciências Agrárias. 2011;32(1):49-62.

Fonseca EP, Valéri SV, Miglioranza E, Fonseca NAN, Couto L. Padrão de qualidade de mudas de Trema micranta (L.) Blume, Cedrella fissilis Veli. e Aspidosperma polyneuron Mull Arg. produzidas sob diferentes períodos de sombreamento. Revista Árvore. 2002;26(4):515-23.

Kamkar B, Al-Alahmadi MJ, Mahdavi-Damghani A, Villalobos FJ. Quantification of the cardinal temperatures and thermal time requirement of opium poppy (Papaver somniferum L.) seeds to germinate using non-linear regression models. Industrial Crops and Products. 2012;35(1):192-8.

Lin S, Liao Y, Roan S, Chen I, Chen P. Growth of noni fruits (Morinda citrifolia L.) and accumulation of phenolic compounds during fruit development. Scientia Horticulturae. 2014;178:168-74.

Mafia RG, Alfenas AC, Siqueira L, Ferreira EM, Leite HG, Cavallazzi JR. Critério técnico para determinação da idade ótima de mudas de eucalipto para plantio. Revista Árvore. 2005;29(6):947-53.

Malavolta E, Vitti GC, Oliveira SA. Avaliação do estado nutricional das plantas: princípios e aplicações. Piracicaba: Associação Brasileira para Pesquisa da Potassa e do Fosfato; 1997. 319p.

Martins FB, Silva JC, Streck NA. Estimativa da temperatura-base para emissão de folhas e do filocrono em duas espécies de eucalipto na fase de muda. Revista Árvore. 2007;31(3):373-81.

Moura JC, Pádua LEM, Moura SG, Torres JS, Silva PRR. Escala de desenvolvimento fenológico e exigência térmica associada a graus-dia do feijãocaupi. Revista Caatinga. 2012;25(3):66-71.

Neis S, Santos SC, Assis KC, Mariano ZF. Caracterização fenológica e requerimento térmico para a videira Niagara Rosada em diferentes épocas de poda no sudoeste goiano. Revista Brasileira de Fruticultura. 2010;32(3):931-7.

Oliveira AS, Steidle Neto AJ, Ribeiro A, Rascon NJL, Rody YG, Almeida AQ. Determinação do tempo térmico para o desenvolvimento de mudas de eucalipto na fase de enraizamento. Revista Brasileira de Engenharia Agrícola e Ambiental. 2012;16(11):1223-8.

Palaretti LF, Mantovani EC, Silva DJH, Cecon PR. Soma térmica para o desenvolvimento dos estádios do tomateiro. Revista Brasileira de Agricultura Irrigada. 2012;6(3):240-6.

Ribeiro GT, Paiva HN, Jacovine LAG, Trindade C. Produção de mudas de eucalipto. Viçosa, MG: Aprenda Fácil; 2001. 122p.

Silva TGF, Zolnier S, Grossi JAS, Barbosa JG, Moura CRW, Muniz MA. Crescimento do girassol ornamental cultivado em ambiente protegido sob diferentes níveis de condutividade elétrica de fertirrigação. Revista Ceres. 2009;56(5):602-10.

Streck NA. A temperature response function for development of the chrysanthemum (Chrysanthemum x morifolium Ramat.). Ciência Rural. 2004;4(1):49-54.

Taiz L, Zeiger E. Fisiologia vegetal. Porto Alegre: Artmed; 2013. 918p.

Urchei MA, Rodrigues JD, Stone LF. Análise de crescimento de duas cultivares de feijoeiro sob irrigação em plantio direto e preparo convencional. Pesquisa Agropecuária Brasileira. 2000;35(3):497-506.

Villa Nova NA, Pedro Jr MJ, Pereira AR, Ometto JC. Estimativa de graus dia acumulados acima de qualquer temperatura base, em função das temperaturas máxima e mínima. São Paulo:

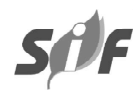

Revista Árvore. 2017;41(2):e410212 
Instituto de Geografia, USP; 1972. 8p. (Caderno de Ciência da Terra, 30).

Wagner MV, Jadoski SO, Lima AS, Maggi MF, Pott CA, Suchoronczek A. Avaliação do ciclo fenológico da cultura do milho em função da soma térmica em Guarapuava, Sul do Brasil.
Revista Brasileira de Tecnologia Aplicada nas Ciências Agrárias. 2011;4(1):135-49.

Xavier A, Wendling I, Silva RL. Silvicultura clonal: princípios e técnicas. Viçosa, MG: Universidade Federal de Viçosa; 2013. 279p. 